\section{“LA CAZA DEL HOMBRE", RECREACIÓN DE UN MOTIVO LEGENDARIO, NOVELESCO E HISTÓRICO EN LA CAZA, DE CARLOS SAURA}

\author{
Felipe Aparicio Nevado \\ Université de Haute Alsace \\ 66, rue des CASTORS \\ 68200 MULHOUSE (Francia) \\ felipe.aparicio@uha.fr
}

\section{“THE HUNT OF THE MAN"; RECREATION OF A LEGENDARY, FICTIONAL AND HISTORICAL MOTIVE IN CARLOS SAURA'S LA CAZA}

\begin{abstract}
The theme of man turned into a prey has been a recurrent one in the discourses and artefacts of human civilisation since prehistoric times. Fables and representations centred on "human hunting" have a meaning that reflects their contextual value as well as their ability to conjure up universal obsessions. The primitive syncretism and the hallucinatory power ascribed by some theoreticians to film images are certainly not alien to this timeless motif - a motif underlying myths which lend themselves to a variety of literary uses. Drawing upon Carlos Saura's film The Hunt, this paper provides an interpretation of the devices used by film language, invested with analogical and symbolic force, in order to absorb and revive "traditional" artistic languages, be they verbal - as most of them are - or plastic languages, thanks to "polyphonic montage", so beloved of Eisenstein, and the oblique reading of History which, at all times, has nourished part of man's imagination.
\end{abstract}

KEY WORDS: Cinema and cinegetic literature; Carlos Saura; manhunt; war and hunting.

Numerosos comentaristas han citado una frase cargada de presagios y reminiscencias ancestrales presente en los diálogos de la película La caza, de Carlos Saura. Es aquella en que se hace alusión al motivo de la caza humana, al tema mítico y arcaico de la "caza invertida" del cazador convertido en presa (Hell, 1994, 220). Estudiosos como Guy H. Word han analizado pormenorizadamente las conexiones entre la plasmación fílmica de un descaste veraniego de conejos llevada a cabo por Saura y el trasfondo documental que fundamenta su visión del hecho cinegético, en particular los escritos sobre el sentido de la caza de Ortega y Gasset o El libro de la caza menor, amenísimo tratado sobre esta modalidad de caza pedestre publicado en 1964 por el maestro indiscutible en la materia: Miguel Delibes. Del mismo modo, el profesor de la Oregon University, reconocido experto en
RESUMEN: El tema del hombre convertido en presa recorre los discursos y artes de la civilización humana desde la Prehistoria. Las fábulas y representaciones en torno a "la caza humana" poseen una significación que refleja su valor contextual y, a la vez, su capacidad para cristalizar obsesiones universales. El sincretismo primitivo y el poder alucinatorio que algunos teóricos han atribuido a la imagen fílmica no podían permanecer ajenos a un motivo intemporal que está en la base de mitos con múltiples ramificaciones literarias. La película La caza, de Carlos Saura, da pie a una tentativa de interpretación de los recursos que utiliza el lenguaje cinematográfico, con su fuerza analógica y simbólica, para absorber y vivificar lenguajes artísticos "tradicionales", verbales en su mayor parte, pero también plásticos, mediante el "montaje polifónico" que evocaba Eisenstein y la lectura oblicua de una historia que fecunda una parcela del imaginario humano de todas las épocas.

PALABRAS CLAVE: Cine y literatura cinegética; Carlos Saura; caza humana; guerra y caza.

el estudio del elemento venatorio en la literatura y el cine hispánicos, ha destacado la faceta de "hábil depredador" (Plagios, 168) que manifiesta Carlos Saura en la incorporación al universo de La caza de postulados estéticos y filosóficos procedentes de diferentes intertextos, así como de figuras inquietantes de la monstruosidad en las que el cine se ha recreado desde sus orígenes. Sin embargo, si dejamos de lado la función de preparación del espectador al desenlace trágico de la cinta, que se atribuye de forma casi unánime por parte de la crítica a la idea de la caza del hombre, apenas se ha explorado la significación intertextual y el sentido de la reelaboración cinematográfica que Carlos Saura imprime a un motivo legendario, histórico y novelesco, universal e intemporal. El objetivo de este ensayo no es otro que focalizarnos en lo que Guy H. Word 
califica de "autoexterminio final de La caza" (Plagios, 175) y ahondar en la estilización y el entrelazamiento que teje la cinta del director aragonés entre las diversas caras de un tema abordado múltiples veces por la literatura y el cine desde sus inicios.

La alusión literal a la transformación del hombre en objeto de caza aparece en las páginas iniciales del guión de rodaje ideado y escrito por Angelino Fons y el mismo Saura, en el curso de un diálogo a cuatro voces entre los protagonistas de la excursión cinegética (Enrique, José, Luis y Paco) (Saura, 29). Sucede durante uno de esos momentos de pausa, de espera, de inactividad y hastío bañados por el sudor, uno de esos tiempos muertos de personajes moribundos por dentro a los que se muestra tan proclive el clima de la historia. A todas luces, el director aragonés no ha elegido en vano un marco espacio-temporal dominado por las colinas esteparias de un coto de caza toledano y un sopor estival, una canícula manchega de luz cegadora, de sol abrasador, de soflama pegajosa que recuerdan los efectos de una atmósfera semejante sobre Meurseault, el emblemático personaje de Albert Camus en El extranjero, caminando junto al mar antes de cometer un crimen absurdo. El mismo calor sofocante, en suma, que reina en la recreación de la matanza de Puerto Hurraco llevada a cabo por Saura en uno de sus últimos trabajos, El séptimo día, película en la que los habitantes de una localidad extremeña son objeto de una caza indiscriminada por las calles del pueblo en un atardecer tórrido. El mismo "sol infernal" de mediodia en un barrio periférico que inunda la secuencia tres de Cazadores' (1996) -y vuelve a evocarse insistentemente en la siguiente secuencia (Saura, 2, 4)-, el corto de Achero Mañas cuyo argumento y construcción formal (primerísimos planos, confesiones ante la cámara, estilo documental, truculencia minimalista) no dejan de recordar significativamente La caza de Saura. El paisaje, del mismo modo que en películas recientes como El rey de la montaña (2007), de Gonzalo López Gallego (en la que también pueden rastrearse correspondencias temáticas y estilísticas con la película de Carlos Saura, además de referentes directos a obras como Deliverance [1972], de John Boorman), no es sólo un marco espacial, un entorno físico, sino un elemento fundamental en la consecución de una atmósfera opresiva y un clímax fatal -en el sentido etimológico-, determinante en el comportamiento y el destino de los personajes, una atmósfera propicia para las situaciones límite y los puntos de ruptura sin posibilidad de retorno.
Conviene recordar exactamente los términos del famoso diálogo en una secuencia que se extiende a lo largo de ocho planos:

8) Enrique mira a Paco algo asombrado

ENRIQUE:

No lo dirás en serio.

9)

$$
\text { JOSÉ: (a Enrique) }
$$

En lo de la caza tiene razón Luis: al conejo se le da pocas oportunidades para defenderse. Cuant[o] más defensas tenga el enemigo, más bonita es la caza, se lucha de poder a poder.

10)

$$
\text { LUIS: (Con sorna) }
$$

Por eso alguien dijo que "La mejor caza es la caza del hombre"

12) Luis se encoge de hombros.

PACO:

$$
\text { ¿Qué dices tú? }
$$

$$
\begin{aligned}
& \text { PACO: (Para él) } \\
& \text { La caza es como todo: el pez grande se come } \\
& \text { al chico. }
\end{aligned}
$$

14)

$$
\text { JOSÉ: }
$$

Eso depende. A veces pasa lo contrario. Mira las pirañas.

15) Paco, sorprendido, deja lo que estaba haciendo.

PACO:

¿Y eso qué es?

JOSÉ se vuelve a LUIS.

JOSÉ:

Cuéntaselo, Luis.

Y luego a PACO.

Sabe mucho de esas cosas. Le ha dado por ahí, y por leer noveluchas de marcianos.

Cabe preguntarse si la cita a la que recurre Luis no actúa como la piedra (de toque) que, lanzada al agua cenagosa 
de un final de dictadura edificada sobre las ruinas de la Guerra Civil, despierta la conciencia del espectador y le sume en el centro de los círculos que genera un motivo cargado de connotaciones. El tema del hombre convertido en presa de sus semejantes recorre cada uno de los discursos y artes que han acompañado a la civilización humana desde la Prehistoria. Sobra decir que la función poético-narrativa del lenguaje y de la imagen en todas sus manifestaciones ha dotado a las fábulas o representaciones en torno a la "caza humana" de una significación metafórica y simbólica que denota su valor contextual y, a la vez, enriquece su capacidad para cristalizar obsesiones universales. Parece evidente así que Saura, de forma más o menos consciente, recrea un motivo omnipresente en la literatura o la iconografía desde la Edad Media manteniendo su anclaje en el presente de un franquismo agónico, víctima de una especie de mixomatosis colectiva que ataca a los "vencedores" de la Guerra Civil. El poso referencial aflora constantemente en el relato fílmico de La caza, por lo que no puede en ningún caso afirmarse que el cineasta se limite a dar una versión cuyo propósito sea traducir en imágenes una objetivación arquetípica de los múltiples modelos que nos proponen el fondo legendario, la literatura novelesca, la escritura histórica e incluso la filosofía, la etnografía o la pintura en modulaciones o variantes tales como el rapto femenino (así lo atestiguan, entre muchos otros, Ortega y Gasset, en "La caza solitaria" [458] desde una perspectiva filosófico-etnográfica, o Toulouse-Lautrec en un plano pictórico de "Un enlèvement", 1892)². Motivo de un modo de seducción primitivo presente en Occidente y en Oriente (Louis Condominas dedica un capítulo de su libro La chasse: et autres essais a la caza ritual de mujeres jóvenes en las zonas montañosas de Vietnam) que, dicho sea de paso, inunda la película de Saura de sensualidad a través del deseo que genera en el joven Enrique la presencia turbadora de la adolescente, la sobrina del guarda tullido.

El sincretismo primitivo y el poder alucinatorio que algunos teóricos han atribuido a la imagen fílmica no podía permanecer ajeno a un motivo intemporal que está en la base de mitos con múltiples ramificaciones literarias. Michel Serceau sintetiza certeramente la cuestión cuando afirma que el cine

Se faisant en même temps le véhicule de tous les thèmes, de tous les mythes qu'a traités ou charriés la littérature, le cinéma relève autant, sinon plus, de l'anthropologie culturelle et de la psychanalyse appliquée que des sciences de la littérature et du langage (Serceau, 2001, 10).

No extraña tampoco que cineastas de otras cinematografías, de la misma generación que el director aragonés, se hayan interesado por el tema otorgándole similar alcance simbólico que Saura en un contexto histórico comparable. Tal es el caso del filme de Peter Fleischmann Escenas de caza en la Baja Baviera (Jagdszenen aus Niederbayern, 1969), en el que los vecinos de un pueblo bávaro persiguen a los marginales y homosexuales del contorno en una cacería organizada durante la fiesta de la siega. Claude Chabrol también nos ha legado su particular visión de una caza al hombre en su maquiavélica L'Invitation à la chasse (1974), una de sus películas menos conocidas fuera de Francia. Sin embargo, el tema había sido tratado en la pantalla sin ambages mucho antes, en una cinta en colaboración de Ernest Beaumont Schoedsack e Irving Pichel: The Most Dangerous Game (1932). En esta película ya clásica, el conde Zaroff, sicópata sádico obsesionado por la pieza cinegética más ardua y temible: el hombre, y Bob Rainsford, veterano cazador de fieras, víctima de un naufragio y acompañado por la deslumbrante Eva, van a afrontar su instinto en una caza-persecución con un desenlace que remite literalmente, aunque fuera de campo, al mito de Diana (en concreto al drama de Acteón devorado por sus propios perros) y, tanto monta, a su variante medieval conocida con el nombre de "paradigma de Sigfrido". Lo sorprendente, lo novedoso, lo que dota a la parábola de Saura de un alcance universal, resulta de la imbricación de lo simbólico en la diégesis de una banal jornada de caza veraniega que acaba precipitadamente como el rosario de la aurora, en un final de western ibérico apocalíptico, con una catarsis nihilista en la que la sangre acaba diluyéndose en el río de una Historia inasumible. Parece natural preguntarse, pues, por el sentido y la forma que otorga el lenguaje fílmico de Carlos Saura a lo que investigadores del hecho cinegético en la Edad Media definen como "le thème du 'chasseur chassé' (paradigme de Siegfried)" (Guerreau, 2000, 31), o, en palabras del binomio de novelistas franceses del XIX Erckmann-Chatrian, "cet étrange phénomène de l'homme à la chasse de son semblable" (Erckmann-Chatrian, 1988, 106). Se trata, no cabe duda, de esa tendencia inconfesablemente humana que coinciden en poner de relieve trabajos muy recientes de antropología histórica dedicados a la guerra de exterminio de los 
nazis contra las partidas de resistentes de Ucrania y de Bielorrusia durante la Segunda Guerra Mundial (Ingrao, Les chasseurs noirs. La brigada Dirlewanguer), la mejor novela del maquis ibérico (Julio Llamazares con Luna de lobos, Justo Vila con La agonía del búho chico, Alfons Cervera con Maquis), testimonios a caballo entre la literatura y la historia como el del de emperador-cazador-soldado Adriano confesando "esa extraña embriaguez que jamás he vuelto a encontrar bajo esa forma" (Yourcenar, 1982, 50), así como los diarios o memorias de filósofos-soldados durante la Primera Guerra Mundial, que traducen el poder orgiástico atribuido por Ortega y Gasset a toda forma de guerra entre hombres $y$, particularmente, a toda guerra cinegética, en la cual unas veces se es presa y otras predador. A modo de ejemplo, la experiencia de artillero vivida por el pensador francés Émile-Auguste Chartier, alias Alain, en la guerra de trincheras de 1914-18, no tiene desperdicio: "J'étais enivré. Si l'on voyait en même temps les coups arriver au but, cette chasse au canon serait un des plus vifs plaisirs. "Homicide point ne seras". Mais qui y pense? [...] Cela me rappelle une autre chasse à l'homme, où je fus homicide d'intention [...] Je veux que l'on sache qu'il n'y a aucune méchanceté dans ces jeux-là. L'ardeur de la chasse y fait tout" (Alain, 1960, 536-37). La historiografía ha desvelado recientemente un secreto a voces: el hecho de que algunas unidades especiales del ejército nazi durante la Segunda Guerra Mundial estuvieran compuestas de antiguos furtivos condenados por la justicia y cuya misión consistía en la caza a muerte de un enemigo sin uniforme y fundido en el medio natural:

Combinant, aux yeux de dignitaires aussi éminents que Hitler ou Himmler, passion cynégétique, violence débridée et cruauté du Sang noir, les braconniers de l'unité s'étaient vu confier la "pacification" et la chasse à des partisans, précisément assimilés, avant même tout contact avec eux, à des bêtes sauvages, à des proies qu'il fallait traquer (Ingrao, 2006, 231).

La novela hispanoamericana utiliza asimismo con bastante frecuencia el símil de la cacería humana. En Butamalón, de Eduardo Labarca, centrada en la guerra entre mapuches y españoles en el siglo XVI, las alusiones, imágenes y metáforas en ese sentido son constantes: "El sargento Hilario Lobo iba de montero con su famoso Auguspin, perro de piel bermeja y negro hocico, conocido por su ferocidad y su denuedo. Los amigos habían descubierto la quebrada en que se escondian los indios fugados de la encomienda" (Labarca, 1994, 219); "La población huía alborotadamente a los cerros, donde Catilebo, con la crueleza que bien le conozco, iba cazando a los españoles como a conejos" (Labarca, 1994, 395). En "Satarsa", uno de sus últimos relatos, Julio Cortázar entrelaza la caza de pura subsistencia de ratas gigantes y agresivas por parte de los guerrilleros emboscados en la selva con otra forma cinegética cuyas resonancias ancestrales y tono de pesadilla nos resultan extrañamente familiares, inscritas en la historia de los países hispanoamericanos en el siglo XX: la caza al subversivo llevada a cabo por las fuerzas represivas de un país dictatorial que muy bien pudiera ser la Argentina de los años 70 y 80 . El diálogo entre Laura y Lozano viviendo en la clandestinidad no deja lugar a dudas:

"-Sí. Pero no nos vamos a quedar siempre aquí cazando ratas.

- Es mejor que pasar al otro lado a destiempo y que las ratas seamos nosotros para ellos" (Cortázar, 1998, 42).

Sin embargo, la temática que nos ocupa le había interesado a Cortázar mucho antes. En uno de sus relatos más famosos, "La noche boca arriba", la caza de enemigos cobra una dimensión mítica y sacrificial en una modalidad cinegética que oculta su crueldad bajo una denominación no exenta de poesía:

La guerra florida había empezado con la luna y llevaba ya tres días y tres noches. Si conseguía refugiarse en lo profundo de la selva [...] quizá los guerreros no le siguieran el rastro. Pensó en los muchos prisioneros que ya habían hecho. Pero la cantidad no contaba, sino el tiempo sagrado. La caza continuaría hasta que los sacerdotes dieran la señal del regreso. Todo tenía su número y su fin, y él estaba dentro del tiempo sagrado, del otro lado de los cazadores" (Cortázar, 1997, 217).

Las referencias susodichas a la guerra como telón de fondo de la caza que nos ocupa, tanto en su vertiente factual como simbólica, no parecen gratuitas si consideramos que desde tiempos inmemoriales la identificación de la guerra con la caza es algo habitual. Ya en la Antigüedad, la caza se había convertido en fuente inagotable de metáforas para la guerra. Los tratadistas no dejan de vincular ambas actividades. Así Jenofonte, en El arte de la caza (siglo IV a. C.), afirma que "la caza es la mejor escuela de guerra" 
(Xénophon, 1970, 12). Julius Pólux, en el siglo II de nuestra era, anota, en sustancia, que la caza es una práctica de guerra porque enseña a capturar lo que está escondido, a resistir a lo que hace frente y a perseguir lo que huye. En un marco más amplio en el plano cultural, aunque limitado a la piel de toro, cabe recordar las palabras recientes de una historiadora del arte: "Toda Hispania, a decir del geógrafo griego Estrabón, contemporáneo de Augusto, era un 'gigantesco coto de caza'. Los pintores, broncistas y artesanos hispanos, a lo largo de todo el mundo antiguo, encontraron en los temas de caza motivo de inspiración" (Núñez, 2006, 6). En cuanto a los protagonistas animales de la caza en la cinta de Saura, los conejos (¿hace falta recordar que la censura franquista redujo el título inicial previsto, La caza de conejos, al genérico La caza?), autores como Varrón y Plinio han dejado constancia de su extrema abundancia en la península ibérica. Increiblemente fértiles, según Varrón, son capaces de sembrar el hambre tras haber devorado la cosecha de cereal en las islas Baleares (Schnapp, 1997, 334). No puede sorprendernos, pues, que algunas películas de culto entre las cuales puede destacarse The Deer Hunter (1978) de Michael Cimino, entretejan un paralelismo constante entre la caza y la guerra y exploren las secuelas psíquicas y morales de la violencia y de la barbarie en la mente del cazador y en su relación con la naturaleza y con sus semejantes. Conviene recordar, por otra parte, que en una entrevista realizada en el año 1969 el propio Saura, comentando las alusiones de La caza a la Guerra Civil española, insiste en el hecho de que "hubiera podido producirse la misma historia si los cazadores hubieran hecho la guerra de Vietnam"3. Los protagonistas de La caza, exceptuando a Enrique, el más joven de la cuadrilla, son todos excombatientes de una guerra civil omnipresente en su memoria y en el escenario de la película. Los recuerdos, los traumas y las secuelas mentales o físicas que el conflicto ha dejado en la memoria de los veteranos y en sus cuerpos se reflejan en el espacio geográfico captado por la cámara. Un paraje habitado por los fantasmas del pasado (el esqueleto de la cueva, cuyo enclaustramiento bien pudiera apuntar a la memoria de los vencidos encerrada bajo siete llaves) y marcado todavía por las cicatrices de la batalla diseminadas por el paisaje. Las alusiones directas o veladas a la guerra (que ha unido a los personajes durante los tres años de la gran cacería entre nacionales y republicanos) aparecen constantemente en la película a través de los diálogos o de visualizaciones de los efectos de la guerra (cráteres producidos por los obuses, planos de la entrada de la cueva donde reposa el despojo del soldado anónimo). Los guionistas anotan, describiendo el paisaje del coto, que "a media ladera se ven una serie de agujeros en la tierra, que son las entradas a galerías y trincheras utilizadas durante una guerra", así como un "nido de ametralladora" (Saura, 24). El paralelismo entre dichos túneles y oquedades defensivas y los bardos o vivares de los conejos parece más que evidente. La filmación subterránea de la entrada del hurón en la madriguera de los conejos, minuciosa y de un poder visual casi documental, en la que sobran las palabras, cobra así valor de metáfora. No obstante, por si las imágenes no fueran suficientemente impactantes, los guionistas han puesto en boca de los personajes frases deliberadamente enigmáticas y ambiguas, con capacidad para evocar el contexto histórico, pero también con gran poder premonitorio en la trama y en la lógica interna de la película. Uno de los ejemplos más claros se produce cuando Luis, durante los primeros compases del grupo de "amigos" en el coto (con amigos así, es bien sabido, no hacen falta enemigos), deja caer que el paraje donde se desarrolla la caza es un "buen lugar para matar, ¿Eh?" (Saura, 24), poco después de que otro de los escopeteros haya pronunciado otra frase que remite a la masacre entre las dos Españas: "aquí murió mucha gente. A montones" (Saura, 24). Y con toda certeza, afirmaciones tales, entre lo perentorio y lo truculento, entretejen nuevos lazos con la percepción de la Guerra Civil por parte de creadores de otros medios que han nutrido al séptimo arte de materia narrativa antes de enriquecerse con sus nuevos modos de contar historias. Un caso paradigmático es el del escritor-cazador Miguel Delibes, que vivió los hechos de cerca y ha meditado (imilitado?) literariamente toda su vida para que el ritual endémico de la violencia hispana no vuelva a repetirse. Uno de sus testimonios autobiográficos, presente en el libro de crónicas cinegéticas titulado Con la escopeta al hombro, es particularmente elocuente: un pasaje trata de la evocación de su época de morralero, de su iniciación a la caza menor junto a su padre y de su existencia marcada para siempre por el estallido de la contienda civil en plena adolescencia: "Naturalmente, yo, por mi edad, asistía a estas excursiones de simple espectador. Más tarde, al cumplir los quince años llegó la guerra y, al levantarse la veda del hombre, se cerró la del conejo" (Delibes, 2000, 34). No está de más recordar que el novelista vallisoletano articula el mismo motivo en Las ratas, donde la caza de subsistencia va acompañada de una forma de caza-acoso tribal, territorial, primitiva 
contra el cazador de ratas por afición de Torrecillórigo, a la vez "bête noire" y cabeza de turco del viejo ratero. En otra de sus novelas emblemáticas, Las guerras de nuestros antepasados, llama poderosamente la atención el idiolecto de los cazadores aplicado a situaciones bélicas o de persecución. Por ejemplo, en uno de los comentarios del tío pacifista de Pacífico sobre la Guerra de los Cien Años: "Hace mucho tiempo de eso, Pacífico; entonces las armas mataban menos y había que estar más rato para hacer el cupo" (Delibes, 2005, 81). La novela abunda en imágenes y alusiones literales a la caza humana: "¿ldeas? Yo corría por correr, doctor, parigual a los conejos, o sea, para que no me cazaran [...]. Bueno, corría y me paraba, a ratos, ¿no? ¿Usted ha visto correr a las liebres una vez que se las levanta de la cama? Pues, tal cual" (Delibes, 2005, 276, 278). Su última novela, El hereje, ofrece una nueva variante a través de la gran batida organizada contra el círculo de los luteranos de Valladolid reagrupados en torno al doctor Cazalla. El personaje principal, Cipriano Salcedo, caracterizado en momentos claves de la obra como un perro de caza buscando un rastro, mediante una imagen que contiene "el destino ulterior previsto por el narrador" (Kristeva, $1994,14)$, irá transformándose en animal perseguido por la jauria de la ortodoxia inquisitorial encarnada por la intransigencia de Felipe II: "Otro criado, recién llegado de Toro, no creía que la gran redada fuera inminente. A juicio de los inquisidores, Cristóbal de Padilla, con sus conciliábulos y los contactos y visitas en la prisión había espantado la caza" (Delibes, 2001, 399). Por otra parte, algunos de los gestos del guarda del coto toledano preparando los hurones en $L a$ caza parecen encontrar un eco fiel en las descripciones del bichero Avelino en El hereje: "El señor Avelino se movía diligentemente y trataba a los hurones con deferencia, les dedicaba palabras dulces y afectuosas $y$, de cuando en cuando, escupía en la palma de la mano y dejaba que el bicho sorbiera la saliva con deleite" (Delibes, 2001, 230). Otros narradores y conocidísimos guionistas del otro lado del charco, como el mejicano Guillermo Arriaga (en candelero por su recién estrenado viraje a la dirección cinematográfica con The Burning Plain [2008] y quien reivindica expresamente su filiación con el enfoque cinegético de buena parte de la obra delibiana), han manifestado la importancia del resorte cinegético en su visión del mundo y, por consecuencia, en la construcción de los personajes que pueblan sus relatos: "Me gusta cazar porque es un rito muy profundo que enfrenta la vida con la muerte, la belleza con el horror. La caza acerca a la verdad de las cosas. Todo mi trabajo es sobre la caza y todos mis personajes se comportan como cazadores. Me gustan los animales y los que más respeto son los que cazo" (Fernández-Santos, 2005, 42).

Uno de los puntos más originales de la cinta de Saura es el hecho de que la caza real contenga una caza-trampa o una caza-pretexto, por decirlo de alguna manera, que, aun teniendo abundantes referentes filmicos o literarios, funciona adoptando una lógica propia tanto en el plano de los encuadres, mediante el recurso masivo al primer o primerísimo plano (resorte estilístico omnipresente igualmente en la citada El rey de la montaña) como en los guiños al espectador que representa el acceso al flujo de conciencia de los personajes, a una voz interior, a un subjetivismo que desvela la hipocresía reinante y el sentimiento de fracaso de una generación perdida, mediante la expresión en voz alta ante la cámara de pensamientos inconfesables. Uno recuerda el crimen amañado en accidente cinegético en La Règle du jeu (1936), de Jean Renoir, cuando el guarda descerraja un tiro al aviador Jurieu después de haberlo confundido con Octave, el tímido enamorado de la mujer del marqués de la Chesnaye. Nos viene igualmente a la memoria el pasaje de Memorias de Adriano durante el cual el emperador, invitado a una cacería por Quieto, se convierte en realidad en objeto de una caza que pretende suprimirle. Caza-atentado a la que escapa gracias a su excepcional condición física y a un golpe de suerte. Adriano permanece impasible, haciendo como si no se hubiera percatado de la encerrona para ajustar cuentas en el momento que más convenga al orden del Imperio:

Antes de remontar hacia el norte, para liquidar el conflicto sármata, volví a ver a Quieto. El carnicero de Cirene seguía siendo temible. Mi primera medida había consistido en disolver sus columnas de exploradores númidas. Le quedaba su sitial en el Senado, su cargo en el ejército regular y el inmenso dominio de las arenas occidentales que podia convertir a gusto suyo en un trampolín o en un asilo. Me invitó a una cacería en Misia, en plena selva, y tramó un accidente en el cual, de haber tenido menos suerte o menos agilidad física, hubiera perdido seguramente la vida. Pero era preferible aparentar que no sospechaba nada y esperar con paciencia (Yourcenar, 1982, 85-6).

Tampoco tiene mucho en común la configuración de la historia sauriana con la caza al hombre que proponen las 
grandes novelas del furtivismo. En relatos como El mundo de Juan Lobón, excepcional narración de Luis Berenguer que recibió el premio de la crítica en 1968, en un clásico de la novela francesa, Raboliot, de Maurice Genevoix, premio Goncourt en 1925, o en la novela Un mâle, del belga Camille Lemonnier, asistimos a la persecución agónica, a la bajada a los infiernos, de los que tal vez sean los últimos hombres libres en la civilización del racionalismo tecnológico imperante en el siglo XX, esa suerte de dictadura mental y material denunciada por Marcuse en El hombre unidimensional. Curiosamente, la Primera Guerra Mundial o la Guerra Civil española vuelven a servir de referentes en las vidas imaginarias de Raboliot o de Juan Lobón, en una guerra larvada de lucha de clases en la que la clase social dominante en el espacio rural, la de los señoritos y nobles terratenientes, animaliza, margina y extermina como a bestias dañinas a los que no aceptan las leyes impuestas para proteger sus privilegios de casta. Es necesario recalcar que la censura dejó pasar una alusión directa (y a la vez alegórico-simbólica, como numerosos elementos del filme) a la cuestión de la guerra de clases, tabú durante la dictadura. La realiza Luis, el bebedor empedernido y lector de relatos de ciencia ficción: "Llegará un día en que los conejos se coman al género humano. Nos invadirán y formarán una nueva civilización. $Y$ como son más pequeños que nosotros habrá lugar para todos y la lucha de clases desaparecerá [...]. Pero antes sostendrán una guerra con las ratas". La asociación entre caza, en especial la mayor, o el ojeo aristocrático -que caricaturizan Luis Berlanga en La escopeta nacional (1978) y Mario Camus en Los santos inocentes (1986)- y oligarquía franquista es, por lo demás, una constante. Patente en películas como Furtivos (1975), de José Luis Borau, que aborda la cuestión en clave psicoanalítica. De igual modo que la novela, la historiografía resalta la afición a la caza mayor del que se proclama a sí mismo "Generalísimo" de España4.

En resumidas cuentas, el mayor logro en el plano temático de La caza tal vez sea su capacidad para cristalizar una obsesión universal despojándola de sus atributos tradicionales, es decir, la "embriaguez" que rememoraba el emperador Adriano, el poder dionisiaco que pone de relieve Ortega y Gasset, el fantasma de la persecución y la pesadilla vibrante que espectadores o lectores buscan y viven por procuración en las salas oscuras o en la soledad fascinante de la lectura. Saura ha huido como de la peste de la "erótica de la caza" que evocan algunos estudiosos de la cuestión desde una perspectiva antropológica: "Algunos cazadores suelen comparar con el placer del sexo la gratificación que llegan a experimentar en la caza. Se diria que la actividad cinegética puede ser un sustituto erótico. La caza es el mundo de los rastros y de los olores, de la persecución y de la captura. Disparar y matar al animal, hacerse con él cuando está rendido, son actividades que proporcionan gran deseo y placer. Existe una erótica de la caza" (Zulaika, 1992, 144). El Eros que representa el impulso sexual suscitado por la adolescente en el joven Enrique, único superviviente del tiroteo en que culmina la historia, aparece contrarrestado por el erotismo frustrado de los veteranos, simbólicamente condensado en el maniquí que sirve de diana. No asistimos, ni en los momentos de mayor despreocupación, a una cacería gozosa, a una confrontación entre instintos que procure esas "vacaciones de humanidad" (Yebes, 2002, 74) de las que brota, según Ortega y Gasset, el placer secreto de la caza. Ya que según el filósofo madrileño:

Si se compara con las otras diversiones -los espectáculos o los juegos deportivos- salta a la vista la superior calidad que posee la afición a la caza. Frente a ella todas esas otras distracciones parecen meros inventos arbitrarios que lo mismo podian existir que no existir, mientras la afición a la caza se encuentra preformada en la condición misma del hombre y brota en zonas mucho más profundas de su ser. De aquí que en su ejercicio participe el hombre entero, arrancándole por completo de su existencia habitual. Por lo mismo es la distracción más radical porque en ella descansa todo el hombre de la vida trabajosa en que suele estar. [...] es una impresión como de haberse evadido no se sabe de qué cárcel o prisión (Ortega, 1985, 454).

Los personajes de Saura matan maquinalmente, en cadena, casi por inercia, sin conseguir escapar ni un solo segundo de la prisión mental en la que se des-viven, encadenados a un destino inextricablemente ligado a la barbarie fratricida, al suicidio y al fracaso, sin posibilidad de sustraerse a la fuerza de atracción del pasado. Del encadenamiento rápido de planos en las escenas de tiro se desprende la sensación de que los personajes se comportan como autómatas, matando el tiempo antes de volver las armas unos contra otros en un espacio laberíntico cuya única salida parece ser una muerte violenta. De ahí la búsqueda de un efecto que sobrepase el verismo documental y dé a la traca cinegética de clausura de La caza un cariz de "caza fantástica" en el sentido medieval de la expresión:

ARBOR Vol. 187748 marzo-abril [2011] 269-277 ISSN: 0210-1963 
[...] contra toda apariencia, no es un film realista, naturalista, verista [...] es su trasfondo lo que en verdad lo define. Es una parábola, casi un cuento oriental, que hoy se presenta corrientemente bajo la forma de ciencia ficción [...].

Ese paisaje mondo, lunar, abrasado por el verano, de planeta extinguido, es un mundo cercado. $Y$ esos tres hombres también lo son, encerrados en unos intereses, que dominan su vida, como una idea fija, monomaníaca. Están solos en aquel páramo y en sus vidas, habitantes de un asteroide" (Villegas, 1967, 81).

Numerosos elementos de la película, en particular la atmósfera canicular, el calor infernal de una excursión que reviste tintes de purgatorio bajo un sol africano, remiten a una re-visión, a un avatar insólito de una vivencia hispana de la muerte: la que desemboca en la expiación colectiva brutal de un grupo de hombres dispuestos a sacarse los hígados los unos a los otros, incapaces de relacionarse de un modo que no sea, como lo anotó Miguel Delibes, "a palos" (Delibes, 2000, 107). La deshumanización que opera la mirada de Saura, la animalización que se instaura en la conciencia de sus personajes, desvela nuevos matices de un fenómeno múltiples veces observado y consignado en sus escritos por visitantes extranjeros que han recorrido España en las épocas más diversas, desde Guicciardini en el siglo XVI, a Richard Ford en el XIX: la pulsión cainita y guerrera imperantes en una meseta esteparia bajo el signo de Sirio. La caza real invertida puede así leerse en primer lugar, en realidad, como una caza de los demonios interiores de la España franquista, pero no menos percibirse, en un plano más alegórico, a modo de personalísima interpretación de una obsesión recogida por la literatura y el imaginario artístico de todos los tiempos y bajo todas las latitudes.

\section{NOTAS}

Recibido: 30 de octubre de 2008 Aceptado: 30 de marzo de 2009
1 El título original del corto era Muerte de un cazador.

2 Dicho cuadro puede contemplarse en el Musée Toulouse-Lautrec de Albi.

3 Declaraciones recogidas por la revista Cinéma n. ${ }^{\circ} 135$ en abril de 1969.

4 No olvidemos el deplorable espectáculo que nos brindó la catástrofe ecológica del "Prestige": mientras el petróleo se extendía imparablemente por el litoral gallego, un jerarca de este régimen y del anterior no consideró necesario ni urgente interrumpir la noble tarea de la caza del corzo en la que se encontraba absorto.

\section{BIBLIOGRAFÍA}

Anónimo (1969): "Propos de Carlos Saura", Cinéma, 135, pp. 23-25.

Berenguer, Luis (2004): El mundo de Juan Lobón, Madrid, Caïrel Ediciones, Biblioteca de relatos de caza.

Cabello-Castellet, George, Marti-Olivella, Jaume and Wood, Guy H. (eds. and introds.) (1998): Cine-Lit, III: Essays on Hispanic Film and Fiction, Corvallis, $O R$, Oregon State University.

Cervera, Alfons (1997): Maquis, Valencia, Montesinos.

Condominas, Louis (1988): La chasse: et autres essais, Paris, L'Harmattan.

Cortázar, Julio (1998): Los relatos, 4. Ahí y ahora, Madrid, Alianza Editorial.

- (1997): Los relatos, 1. Ritos, Madrid, Alianza Editorial.

Delibes, Miguel (1985): Aventuras, venturas y desventuras de un cazador a rabo, Barcelona, Destino.

- (2000): Con la escopeta al hombro, Barcelona, Destino, Colección Destinolibro, volumen 250.

- (2001): El hereje, Barcelona, Destino.

Alain (1960): Les idées et les âges, en Les passions et la sagesse, Bibliothèque de la Pléiade, Paris, Gallimard.
- (2005): Las guerras de nuestros antepasados, Barcelona, Destino, Colección Destinolibro, volumen 196. 
Erckmann-Chatrian (1988): Hugues-leloup, en Contes et romans nationaux et populaires, Tome III, Paris, Pauvert Tallander.

Fernández-Santos, E. (2005): "Guillermo Arriaga, el cazador que escribe", Noticias y rodajes, El País, 2 de diciembre, p. 42.

Genevoix, Maurice (1983): Raboliot, Paris, Bernard Grasset.

Guerreau, Alain (2000): "Les structures de base de la chasse médiévale", en Paravicini Bagliani, Agostino y Baudouin Van den Abeele (recop.), pp. 25-35.

Hell, Bertrand (1994): Le sang noir. Chasse et mythe du sauvage en Europe, Paris, Flammarion.

Ingrao, Christian (2006): Les chasseurs noirs. La brigade Dirlewanger, Paris, Perrin.

Kristeva, Julia (1994): Le temps sensible, Paris, Gallimard.

Labarca, Eduardo (1994): Butamalón, Madrid, Anaya \& Mario Muchnick.

Larraz, Emmanuel (1973): El cine español, Paris, Masson et Cie.

Lemonnier, Camille (1977): Un mâle, Verviers, Marabout.

Llamazares, Julio (2006): Luna de lobos, Barcelona, Seix Barral.

Mañas, Achero: Guión de Cazadores, Sec. 1.- Entrevistas niños. Imágenes ani- males muertos (www.achero.es/en/ Hunters/script_Cazadores.pdf).

Núñez, Florencia (2006): "La constancia de una noble tierra", El Periódico Extremadura, Suplemento Caza y Pesca, 19 de enero.

Ortega y Gassset, (1945): "La caza solitaria", en Obras completas (1983), Tomo IX, Madrid, Alianza Editorial, pp. 451-58.

- (1942): Prólogo a Conde de Yebes, pp. 15-89.

Paolini, Gilbert y Paolini, Claire J. (eds.) (1999): LA CHISPA'99: Selected Proceedings, New Orleans, LA, Tulane University.

Paravicini Bagliani, Agostino y Baudouin Van den Abeele (recop.) (2000): La chasse au Moyen âge. Société, traités, symboles, Firenze, Sismel, Edizioni del Galluzzo.

Saura, Carlos y Fons, Angelino (1964): Guión de La caza, Filmoteca Nacional.

Schnapp, Alain (1997): Le chasseur et la cité: chasse et érotique dans la Grèce Ancienne, Paris, Albin Michel.

Serceau, Michel (2001): Étudier le cinéma, Paris, Éditions du Temps.

Vila, Justo (2004): La agonía del búho chico, Badajoz, Del Oeste Ediciones.
Villegas López, Manuel (1967): Nuevo Cine Español, San Sebastián, Ediciones del Festival de San Sebastián.

Wood, Guy H. (2003): "Plagios, plagas y descastados en La caza de Carlos Saura", Letras Peninsulares, 16.1, pp. 163-79.

- (1999): "La inspiración prehistórica e iconográfica de La caza de Carlos Saura", en Paolini, Gilbert y Paolini, Claire J. (eds.), pp. 359-73.

- (1998): "La parodia cinegética de Berlanga: La santa escopeta y la recreación nacional", en Cabello-Castellet, George, Marti-Olivella, Jaume and Wood, Guy H. (eds. and introds.), pp. 144-56.

- (2003): "El objetivo cinegético. La poética venatoria del séptimo arte", Litoral, Revista de la poesía y el pensamiento, n. ${ }^{\circ} 235$, pp. 36-45.

Xénophon (1970): L'art de la chasse, Paris, CUF, Les Belles Lettres.

Yebes, Conde de (2002): Veinte años de caza mayor, Sevilla, Ediciones Al Andalus.

Yourcenar, Marguerite (1982): Memorias de Adriano, traducción de Julio Cortázar, Barcelona, Edhasa.

Zulaika, Joseba (1992): Caza, símbolo y eros, traducción de Lurdes Auzmendi, Madrid, Editorial Nerea. 